\title{
Alejandra Pizarnik e a Condessa Sangrenta: uma análise do simbólico nas ilustrações góticas de Santiago Caruso
}

Emilio Soares Ribeiro

Resumo: O presente trabalho se volta para a análise das representações imagéticas que o ilustrador Santiago Caruso faz dos símbolos góticos da obra A Condessa Sangrenta, da escritora Alejandra Pizarnik. Considerando a importância de se analisar as peculiaridades das linguagens envolvidas e como se relacionam na construção dos significados da obra em estudo, investigamos como Caruso, utilizando técnicas que incluem o esgrafiado, representou os símbolos da morte, do sangue, do espelho e do vermelho, que interagem no conto para conferir-lhe um caráter gótico.

Palavras-Chave: Santiago Caruso; Alejandra Pizarnik; símbolos góticos; ilustração.

Abstract: Alejandra Pizarnik and The Bloody Countess: an analysis of the symbolic in Santiago Caruso's gothic illustrations - This paper focuses on the analysis of imagetic depictions made by the illustrator Santiago Caruso based on The Bloody Countess' gothic symbols, written by Alejandra Pizarnik. It inquires how Caruso has depicted, using techniques that includes graffito, the symbols of death, blood, mirror and redness that interact to give the tale its gothic aspect, by considering important peculiarities of the language involved and how they relate to each other in the meaning construction of the artwork here studied.

Keywords: Santiago Caruso; Alejandra Pizarnik; gothic symbols; illustration.

\section{Introdução}

Influenciada pelo simbolismo francês de Rimbaud e Mallarmé, e pelo surrealismo de Enrique Molina e Olga Orozco, a escritora argentina Alejandra Pizarnik (1936-1962) 
se destacou por uma vasta produção poética e por algumas obras em prosa, entre as quais estão ensaios literários, diários pessoais e a novela gótica A Condessa Sangrenta (1917). Ao utilizar palavras que aludem muitas vezes ao fantástico, a obra de Pizarnik aponta para uma fuga da alienação do dia a dia. Somando esse toque maravilhoso a um caráter histórico, a obra A Condessa Sangrenta (1971) narra a história da condessa húngara Erzsébet Báthory, condenada em 1611 pelo assassinato de seiscentas e cinquenta mulheres. O livro reúne as impressões de Pizarnik acerca de Erzsébet Báthory, la Comtesse sanglante, poema em prosa escrito pela poeta francesa Valentina Penrose (1898-1978) em 1962. Envolta em mitos que naturalmente catalisam aspectos ficcionais e fantasiosos, a saga da condessa Báthory foi retratada por Pizarnik com ênfase em seu caráter erótico, sombrio e simbólico.

A publicação da obra pela editora Tordesilhas, em 2011, traz ilustrações de Santiago Caruso, artista argentino famoso por outros trabalhos no âmbito do surreal, do gótico e do fantástico. Representadas em galerias e museus na Argentina, nos Estados Unidos, no México, na Espanha e no Reino Unido, suas obras se destacam pelo vigor do traço e pelas técnicas únicas de que faz uso para criar o simbólico e o fantástico em pintura.

Em suas ilustrações da obra de Pizarnik, Caruso faz uso da técnica de esgrafiado, nanquim aplicado sobre uma cartolina revestida, que é então raspada para a retirada do excesso de tinta e geração de luz. A coloração é posterior, em têmpera ou acrílico. A escolha do esgrafiado como técnica de pintura permitiu ao artista evocar um tom de dureza antiga na forma, de modo que pudesse imprimir às ilustrações um caráter mais sombrio, o que é próprio do gótico.

Para embasarmos a discussão sobre elementos textuais e visuais em livros ilustrados e para que possamos analisar a relação entre as imagens de Caruso e o texto literário por elas ilustrado, utilizaremos, entre outras, as teorias de Nodelman (1988) e Schwarcz (1982). Para a investigação do simbólico na obra da escritora argentina, o trabalho será baseado em autores como Chevalier e Gheerbrant (2001), Cirlot (1984) e Ribeiro (2007; 2010). Na análise e interpretação dos símbolos, buscamos nos isentar de associações precipitadas (LURKER, 1997, p. 667) e evitamos reduzir o sentido desses símbolos de modo que seu significado não se resumisse a "uma insignificância alegórica ou atributiva" (CIRLOT, 1984, p. 5). Da mesma forma, não esgotamos nenhum dos domínios associados à concepção de representação simbólica e aos símbolos aqui analisados.

\section{A ilustração como interpretação}

As ilustrações de obras literárias ainda são com frequência entendidas como obras que esclarecem, enobrecem ou até mesmo deturpam o texto primeiro. Ao estigmatizar a ilustração, essa visão tradicional priva-a de seu papel produtor de significados. Visões como essas, que tendem a negligenciar a importância da ilustração na construção dos significados da literatura, se devem, em parte, à falta de conferência de um caráter artístico 
a essa modalidade de expressão, dotada de um "status secundário" (BEHRENDT, 1997, p. 24). Um exemplo desse preconceito é apontado por Alberto Manguel (2001, p. 20): ele nos lembra que o escritor Gustave Flaubert não aceitava que suas obras fossem ilustradas, alegando que "a descrição literária mais bela" seria "devorada pelo mais reles desenho".

No presente trabalho, todavia, entendendo que "o signo não tem um lugar fixo e estável em uma estrutura" (SOUZA, 2006, p. 158), evitamos projetar "uma lógica espacial de controle de um dado território onde os signos são encontrados bem alojados". Ao contrário, optando por perceber os fluxos temporais nos quais novos significados são produzidos, ressaltamos a importância da análise da relação entre as linguagens envolvidas, suas peculiaridades e como se relacionam na construção dos significados da obra analisada.

A ilustração se aproxima do texto verbal por sua "natureza interpretativa" (PEREIRA, 2008, p. 70). Como em toda interpretação, os signos que compõem uma imagem não consistem nos signos da obra literária de que foram ilustração, mas os representam de diversos modos. Tais representações ocorrem apenas por ocasião do encontro desses signos com o intérprete, o leitor da obra, em cuja mente eles se desenvolverão, constituindo-se em novos signos, interpretantes dos primeiros. Os textos a que temos acesso são signos que compomos a partir de nossas vivências: nossa consciência reage ao mundo, fazendo-nos responder naturalmente aos fenômenos, traduzindo-os "nos termos da nossa própria experiência". As ilustrações, assim, admitem "uma leitura limitada apenas pelas nossas aptidões" (MANGUEL, 2001, p. 22-27).

Essa vida infinita que cada intérprete confere à imagem por meio de sua interpretação permite que, atuando como um "participante em uma discussão contínua sobre significado", ele se constitua em um "ser cultural", e a interpretação, em algo "subjetivo e suscetível a restrições", como defende Bal (2009, p.12). ${ }^{1}$ Entendemos qualquer interpretação como uma maneira de modificar, inevitavelmente, os signos a que somos expostos no dia a dia. Devido ao movimento constante do signo, que está sempre se transformando (SOUZA, 2006), as representações diferem necessariamente daquilo para o qual elas apontam. Assim é com as ilustrações: o trabalho realizado pelo ilustrador não coincidirá com as imagens que o leitor faz das passagens que lê da obra literária.

A ilustração mantém uma relação próxima com o texto literário que representa. Unidas em um só volume, texto verbal e ilustração pertencem a um mesmo tempo e espaço (aquele do leitor). Porém, embora o leitor, vivendo entre as ilustrações que o livro traz e as imagens que o texto escrito excita em sua mente, tenha a impressão de estar diante de uma única obra, temos linguagens oriundas de espaços e épocas diferentes.

Consideramos as ilustrações como obras autônomas e dotadas de ideologia. Aspectos que não se relacionam à narrativa escrita, mas que dizem respeito ao universo da ilustração, como o peso visual dos elementos que compõem a imagem, o direcionamento de tensões

1 Interpretation is both subjective and susceptible to cultural constraints. They define each reader as a cultural being; a participant in a continuous discussion about meaning (BAL, 2009, p.12). 
entre eles ou a ilusão de movimento produzida pelos elementos estáticos da figura, podem integrar as estratégias adotadas pelo ilustrador para ressaltar determinado significado ou ideologia de seu interesse.

Apesar das peculiaridades de cada um dos signos, os verbais e os visuais, as representações que o ilustrador faz da literatura não devem ser percebidas pelo analista de modo isolado. Na análise das representações que as ilustrações fazem de uma obra escrita, a ânsia por uma compreensão absoluta dos contornos entre os sistemas sígnicos relacionados, dividindo-os em códigos isolados (verbal, pictórico, gráfico, entre outros) e em leques extensos de subdivisões, desviaria a atenção da relação entre os textos envolvidos e descaracterizaria as ilustrações como representações de algo anterior. A separação dos signos deve ocorrer apenas para efeito de descrição.

\section{O simbólico de A Condessa Sangrenta: as ilustrações góticas de Caruso}

Devido aos crimes cruéis que teria cometido e aos mistérios sombrios que envolvem a sua história, a condessa Erzsébet Báthory (1560-1614), uma das mulheres mais ricas da Hungria de seu tempo, tornou-se uma personagem histórica bastante lembrada dentro da cultura gótica, inspirando diversos relatos e obras literárias e fílmicas.

Em A Condessa Sangrenta, em tom que beira o sarcasmo, Alejandra Pizarnik (2011), ao se ocupar dos detalhes da vida de Erzsébet Báthory à época em que esta habitava o castelo de Csejthe, no início do século XVII, descreve crimes hediondos por ela cometidos, fazendo uso de várias representações simbólicas.

Torturas com tesouras, pinças e atiçadores, e martírios em uma grande gaiola ou em uma virgem de ferro ${ }^{2}$ estão entre as atividades da condessa, que se deleitava em observar a vida das jovens que contratava para realizar trabalhos em sua propriedade esvaindo-se, com a morte tomando-lhe o lugar e produzindo o sangue que, além de entretê-la, serviria para banhá-la e rejuvenescê-la. A morte e o sangue dela oriundo estão entre os símbolos de que faz uso Pizarnik (ibidem) para descrever as crueldades praticadas por Báthory. Aos dois se somam o espelho e o vermelho, com os quais se associam em diferentes contextos da narrativa, reforçando a ideia de que "os símbolos normalmente não aparecem isolados, mas unem-se entre si, dando lugar a composições simbólicas" (RIBEIRO, 2010, p. 47).

A morte, o primeiro desses símbolos, é representada na literatura de diversas formas. Chevalier e Gheerbrant (2001, p. 621) apontam-na como "o aspecto perecível da existência", como indicação daquilo que "desaparece na evolução irreversível das coisas". Estando associada aos rituais de iniciação, a morte "tem um valor psicológico: ela liberta das forças negativas e regressivas, ela desmaterializa e libera as forças de ascensão

2 Máquina de tortura do século XVIII. Em forma de cápsula, encerrava um ser humano e perfurava seus pontos não vitais. 
do espírito" (ibidem). Esse poder regenerativo da morte é um dos aspectos que caracterizam a condessa sangrenta como uma personagem literária. Usando "a libido como vontade de poder" (TREVISAN, 2011, p.58) e buscando a imortalidade, ela aprende a "olhar morrer" (PIZARNIK, 2011, p.40) para minimizar suas dores e morbidez e, assim, alcançar esferas mais altas.

Por vezes, a morte é retratada como uma entidade feminina. Destaco a deusa romana Mors, ${ }^{3}$ cuja própria designação em latim, mors-mortis, é do gênero feminino. Na obra A Condessa Sangrenta, a morte se confunde com a própria condessa, cujos "olhos lúgubres [...] se punham a reluzir" (ibidem, p. 20) cada vez que jovens costureiras eram condenadas à tortura por sua criada Dorko. Uma amostra dessa representação de Báthory como personificação da morte é a analogia traçada por Pizarnik (ibidem, p.11) entre a dama do castelo e a virgem de ferro, a "dama metálica": "Nua, maquiada, enfeitada com joias, com loiros cabelos que chegavam até o chão, um mecanismo permitia que seus lábios se abrissem em um sorriso, que os olhos se movessem" (ibidem, grifo meu).

Personificando a máquina de tortura e conferindo-lhe feições femininas, Pizarnik (ibidem) faz com que ela e a condessa se associem intensamente, de forma que o leitor perceba as ações mutiladoras da engrenagem como sendo realizadas pela própria personagem.

Para que a "Virgem" entre em ação é preciso tocar algumas pedras preciosas de seu colar. Responde imediatamente com horríveis sons mecânicos e muito lentamente ergue os brancos braços para que se fechem em perfeito abraço sobre o que esteja próximo dela - nesse caso uma moça. O autômato a abraça e já ninguém poderá soltar o corpo vivo do corpo de ferro, ambos iguais em beleza. De repente, os seios maquiados da dama de ferro se abrem e aparecem cinco punhais que atravessam sua vivente companheira de longos cabelos soltos como os seus. (ibidem, p.11, grifo meu)

Ao representar tal relação, Caruso faz com que a virgem de ferro e a condessa se confundam para o intérprete (figura 1). Para isso, retratando a "dama" em um plano aproximado, ele direciona as tensões para o centro da ilustração, que passa a ser o foco, reforçado pela tonalidade avermelhada em um todo branco e preto. ${ }^{4} \mathrm{~A}$ identidade facial da dama é, na edição do livro, em parte ocultada (figura 1).

3 "Enquanto, na Grécia, a Morte está personificada num gênio masculino, Tânato, em Roma, é considerada uma deusa, Mors, ou então uma pura abstração personificada" (GRIMAL, 2000, p. 319).

4 Ao empregar, por meio do uso de aquarela e outras misturas, o vermelho como único tom colorido em todas as pinturas, Caruso permite que as tensões se voltem para elementos específicos dentro de cada ilustração, realçando-os. Confirma-se, assim, a ideia de Nodelman (1988, p. 60), segundo a qual "as implicações emocionais das cores são particularmente claras naqueles livros ilustrados em que há uma cor predominante". 


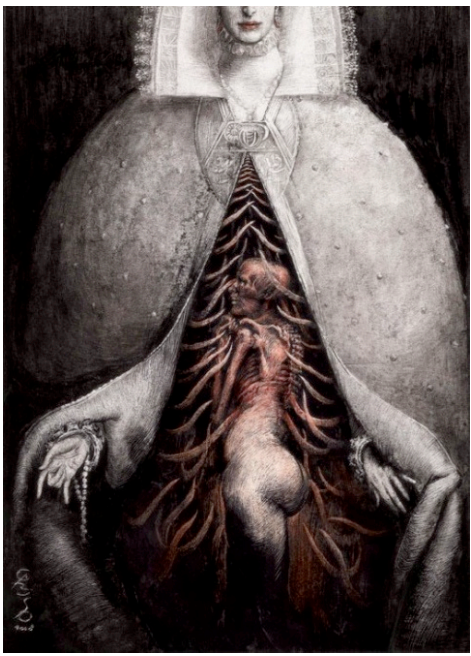

Fig. 1. O abraço da virgem

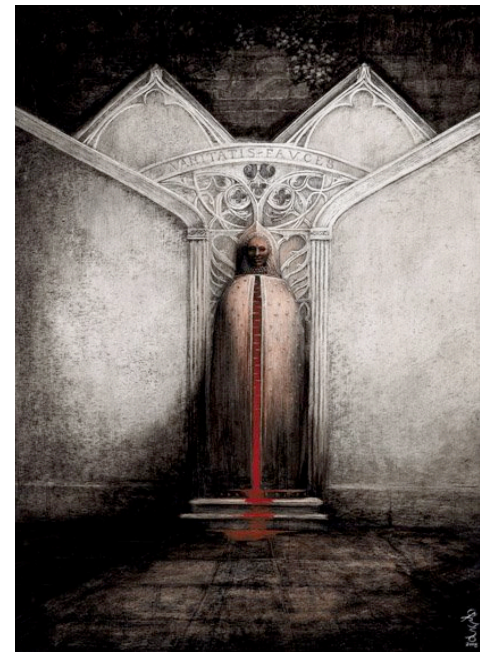

Fig. 2. A virgem de ferro

Assemelhando-se a costelas humanas, os signos que representam os punhais da virgem de ferro na ilustração (figura 1) consistem naquilo que Santaella (1985, p.64) chama de "possibilidades do efeito de impressão" produzidas no intérprete. Em outras palavras, ao estarem no lugar de algo com o qual compartilham aspectos qualitativos (a forma, no caso em estudo), eles fortemente sugerem aquilo que representam.

$\mathrm{Na}$ outra ilustração que retrata a virgem de ferro (figura 2), Caruso representa o lado erótico da personagem da obra de Pizarnik. A escritora nos mostra que, "durante suas crises eróticas, escapavam de seus lábios palavras procazes destinadas às supliciadas. Imprecações soezes e gritos de loba eram suas formas expressivas enquanto percorria, excitada, o tenebroso recinto" (PIZARNIK, 2011, p.18). Assim, reforçadas pelo mito de que Báthory era homossexual e de que se excitava ao torturar suas vítimas, algo que permeia toda a narrativa, as descrições de Pizarnik dão um caráter erótico à condessa e a suas práticas brutais. Basta observarmos a recorrência de expressões de cunho sexual na obra, entre elas, nua, lábios, sons, abraços e seios, em destaque nas citações anteriores. A própria escolha de "moças altas, belas e resistentes" (ibidem, p.17) para suas torturas desumanas e os tipos de martírios a que as submetia (a queima de papel embebido em óleo entre suas pernas, por exemplo) denotam a voluptuosidade da condessa cruel.

Em sua ilustração da virgem de ferro (figura 2), Caruso nos traz uma grande estrutura esbranquiçada e, ao centro, em tom de pele, o autômato, respectivamente como representações icônicas do corpo de uma mulher com as pernas abertas e de sua vagina que sangra. Ele organiza os elementos de forma que a cabeça da virgem de ferro ocupe, dentro do contexto sexual sugerido, a posição do clitóris, e as composições pontiagudas que surgem por detrás da virgem sugiram seios exangues que descansam. 
Explorando com detalhes a virgem de ferro em sua esfera erótica, Caruso retrata o instrumento de modo a revelar características da própria condessa, invadindo a sua intimidade. Um agente externo à cena apresenta ao leitor a imagem da vagina (figura 2) e, ao mesmo tempo, apresenta (como se refletida nela ou inerente a ela) a visão da condessa. Assim, a forma como é apresentada a virgem reforça essa invasão de nível sexual sofrida pelas vítimas da dama de Csejthe, violação causada pela própria condessa.

A escolha da editora pela referida ilustração (figura 2) para a capa do livro, uma capa figurativa de caráter referencial, antecipa, para o leitor, a relação entre os meios sanguinários utilizados pela condessa e o poder que a libido produzida durante as execuções Ihe conferia: "os gemidos de dor das jovens torturadas" reverberavam "os vagidos do orgasmo" (TREVISAN, 2011, p. 58). Ao evocar impressões de nível erótico, associadas à violência, a capa é ainda mais expressiva pela presença do vermelho que emana da virgem e que confere um peso visual à abertura da máquina. Esse peso do detalhe em vermelho deriva da organização dos elementos que compõem a ilustração, bem como das nossas próprias expectativas, visto que o significado de uma ilustração é também oriundo do conhecimento prévio e das associações que nossa experiência permite traçar (NODELMAN, 1988).

Recorro a Guimarães (2002), que, baseado em argumentos da física, explica que a expressividade da cor vermelha provém do seu comprimento de onda. Na escala que estabelece a luz visível, tem-se os limites de 380 a 760 milimícrons $(\mathrm{m} \mu)$, aproximadamente, isto é, não conseguimos ver raios luminosos inferiores a $380 \mathrm{m \mu}$ (os ultravioletas) nem os superiores a $760 \mathrm{m \mu}$ (os infravermelhos), de modo que o efeito de agressividade evocado pelo vermelho provém de sua posição no limiar entre as cores visíveis e invisíveis ao olho humano $(760 \mathrm{m \mu})$. "Daí então deriva o aspecto cultural, o código hiperlingual, como define o autor, que está ligado a ideias de sentimentos extremos, como paixão, violência etc" (RIBEIRO, 2007, p. 96).

Se considerarmos que, assim como acontece com todo signo, as conotações que envolvem a cor vermelha são fortemente induzidas pelos próprios signos a ela relacionados, essas propriedades do vermelho apontadas por Guimarães se tornam ainda mais expressivas devido à organização dos elementos dentro da ilustração de Caruso e à consequente criação de associações de cunho sexual. O vermelho da virgem que sangra remete à violência, incluindo a sexual, porque a ocorrência do sangue em um contexto específico, como o apresentado, pode gerar no intérprete efeitos relacionados a aspectos como virgindade e estupro.

Embora não faça referência ao estupro propriamente dito, Pizarnik (2011) descreve outros tipos de violência sexual cometidos pela condessa. Entre eles está a humilhação sofrida pelas pobres costureiras ao terem que trabalhar despidas sob o olhar da soberana. Trajando suas vestes humanas, a condessa (símbolo da morte) literalmente despia suas vítimas. Pizarnik associa tal cena à própria alegoria da Morte como ser personificado e à Dança da Morte, momento em que as criaturas escolhidas são contempladas enquanto agonizam e desfalecem. Considerando o prazer que as torturas davam à condessa, 
a escritora também traça uma relação análoga entre o próprio orgasmo e o desfalecimento do ser. "Se o ato sexual implica uma espécie de morte, Erzsébet Báthory precisava da morte visível, elementar, grosseira, para poder, por sua vez, morrer dessa morte figurada que vem a ser o orgasmo" (ibidem, p. 20). Assim, regozijando-se de prazer, a condessa despossuía as jovens moças como a morte despe seus/suas escolhidos/as.

$\mathrm{Na}$ interpretação que faz da morte como símbolo, Santiago Caruso novamente assinala expressivamente a distinção entre o branco, o preto e o vermelho, de forma que a maneira como ele organiza os elementos dentro da pintura permita que os detalhes em vermelho sejam acentuados. Fazendo isso, Caruso outra vez confere ao vermelho um peso visual diferenciado. Ao criar cortinas de um vermelho vívido que se abrem para um fundo branco, o artista emoldura a cena em que uma mulher (provavelmente uma costureira) dança com a Morte. À medida que o tempo transcorre, observamos a morte despi-la de sua carne e de seus músculos e cumprir o seu trabalho ao fim da dança.

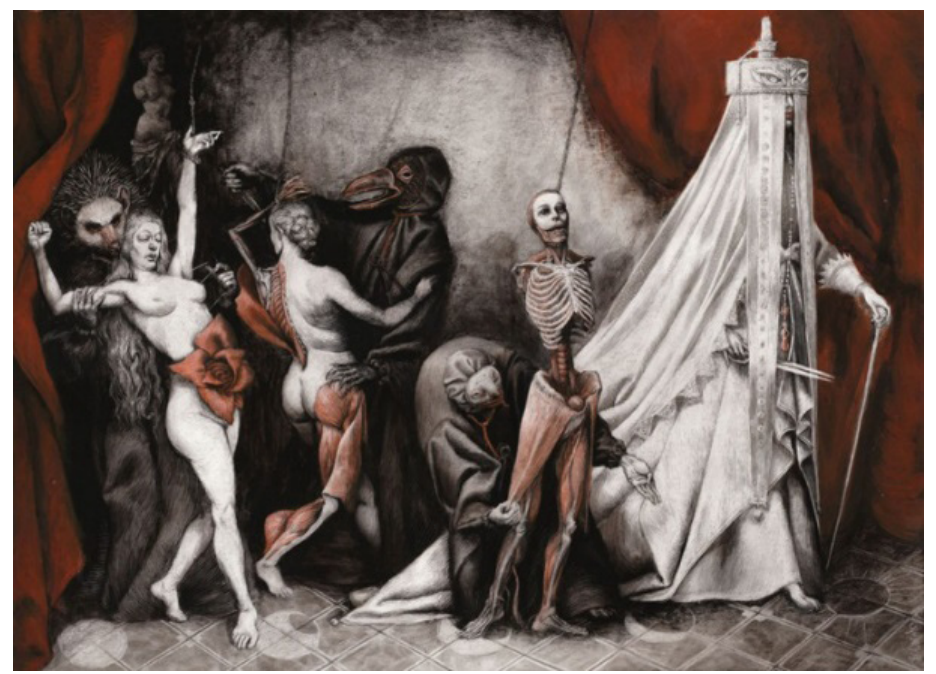

Fig. 3. A dança da Morte

Suspensa como um fantoche, alegoria do ser humano como refém da "Dama que assola e cresta como e onde quer" (PIZARNIK, 2011, p. 20), a vítima dança graças à ilusão de movimento conferida à imagem. Tal ilusão provém da narrativa contínua (continuous narrative) que as figuras da costureira representando estágios em ordem cronológica produzem. Schwarcz (1982, p. 24) chama de continuous narrative essa aparição de um personagem em dois ou mais locais/posições diferentes na mesma ilustração, enquanto o cenário permanece imutável. "Visto que tendemos a 'ler' as imagens em livros de imagens movendo nosso olhar da esquerda para a direita, normalmente assumimos que as figuras de personagens viradas para a direita estão se movendo para a frente" 
(NODELMAN, 1988, p. 163)..$^{5}$ É o que acontece na referida ilustração: temos a impressão de que a ação desempenhada pela figura da vítima, à esquerda, ocorre antes das outras, à direita. E a caracterização de várias ações acontecendo em uma só imagem se dá graças à visão panorâmica do cenário, algo que o texto verbal pode representar indiretamente, como mostram Nicolajeva e Scott (2006).

Usando o vermelho para conferir peso visual à decadência do corpo, Caruso destaca o abdômen que se abre em uma rosa rubra, deixando brotar o que parece ser o intestino da vítima. Ao virá-la de costas para a plateia, a Morte faz questão de tornar visível a degeneração ininterrupta da carne e dos músculos, também destacados em tom vermelho, até que, ao fim da evolução, a representação branca que carrega um cetro e uma tesoura tenha lhe ceifado a vida. Considerando que "imagens dos mesmos personagens em posturas diferentes ou dos mesmos cenários sob condições diferentes [...] transmitem um senso de ação contínua" (NODELMAN, 1988, p. 159), , ${ }^{6}$ podemos afirmar que a noção de passagem temporal, que reforça a representação da ação, é ainda mais visível devido aos desenhos, no piso do palco onde a dança ocorre, da evolução da lua em suas fases e devido às diferentes identidades que a própria Morte assume no decorrer do número (lobo, corvo, dama de branco...). Aqui, as figuras da morte e da condessa se sobrepõem ainda mais, visto que, em diferentes momentos da narrativa, Erzsébet Báthory é apresentada por Pizarnik (2011) como tendo alguma relação com cada uma destas três representações da morte: 1) O brasão de sua família apresentava três dentes de lobo selvagem, emblema que combinava com sua personalidade predatória e ferina; 2) Báthory é descrita por Pizarnik (ibidem, p. 8) como tendo "cabelos da cor suntuosa dos corvos"; 3) Fisicamente, a condessa era "uma figura silenciosa de palidez legendária" (ibidem) e por vezes é descrita pela escritora como trajando um vestido branco (que se torna vermelho após as torturas), "a sonâmbula vestida de branco" (ibidem, p. 15).

Na obra escrita, a analogia entre a condessa e a Morte se explica também pelo desejo da protagonista em permanecer jovem: encarnando a própria morte, como haveria de morrer? Como bem aborda João Silvério Trevisan (2011, p. 59), em seu posfácio do livro, o desejo extremo da condessa pelo rejuvenescimento seria "uma versão tosca da engenharia erótica que a atualidade banalizou, com suas bolsas de silicone, próteses, implantes e operações plásticas que buscam, tal como ela, domar a velhice para superar a morte". O narcisismo de Báthory e sua rejeição ao envelhecimento são ainda realçados pela descrição que Pizarnik (2011, p. 33) faz do espelho que a protagonista possuía e que ela própria havia desenhado: "apresentava umas saliências onde apoiar os braços de maneira a permanecer muitas horas diante dele sem se cansar".

5 Since we tend to "read" the pictures in picture books by moving our glance from left to right, we usually assume that figures of characters pointed toward the right are moving forward" (traduzido pelo autor).

6 "Images of the same characters in different postures or of the same settings under different conditions [...] convey a sense of continuing action" (traduzido pelo autor). 
Habitante do espelho, Báthory é, por natureza, uma figura melancólica, e tal relação dá nome ao capítulo $O$ Espelho da Melancolia, da obra escrita, que trata de apresentar essa morada como um local de contemplação e, principalmente, de inércia. Como descreve Pizarnik (ibidem, p.34), “uma cor invariável rege o melancólico: seu interior é um espaço cor de luto; nada acontece ali, ninguém entra. É um palco sem cenários, onde o eu inerte é assistido pelo eu que sofre por essa inércia". Temos a presença do espelho como símbolo do duplo: um eu que, por meio das agonias que promove às empregadas e dos prazeres sexuais, alivia e pode apagar "a silenciosa galeria de ecos e de espelhos que é a alma melancólica" (ibidem); e outro eu que, estático e taciturno, vive "um ritmo transtornado", "a lentidão exausta da gota d'água caindo de tanto em tanto" (ibidem). Em termos gerais, o duplo consiste em "qualquer modo de desdobramento do ser" (FRANÇA, 2009, p.7). O outro gerado representa uma faceta desse ser, "geralmente uma que está escondida, ignorada, reprimida ou negada pelo personagem que foi duplicado", como aponta Carroll (1990, p.46). ${ }^{7}$

Na representação do duplo, bem comum à narrativa gótica, Caruso enfatiza essa discrepância que há entre o lá fora, marcado pela nitidez da condessa, cuja roupa apresenta detalhes em um vermelho intenso; e o lá dentro, uma região turva e inerte em que nada brota.

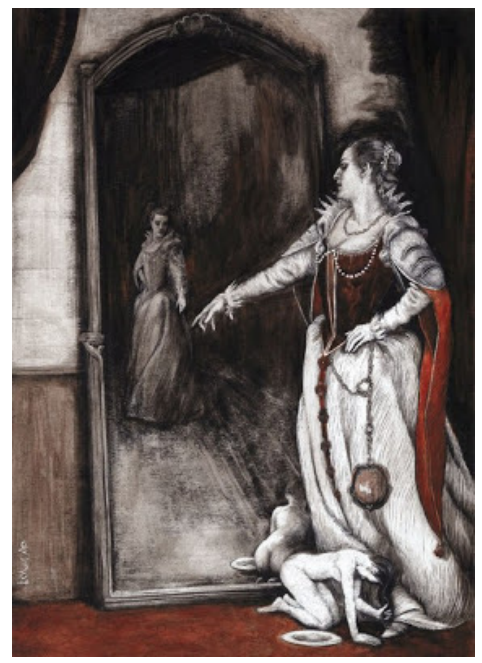

Fig.4. O espelho como símbolo do duplo

A profundidade desproporcional aplicada à imagem da condessa no espelho, em oposição ao reflexo da moça que sucumbe a seus pés (figura 4), representa de forma expressiva a tentativa sempre fracassada de resgate desse eu sombrio. Ao retirar a ênfase

7 A character or set of characters is multiplied into one or more new facets, each standing for another aspect of the self, generally one that is either hidden, ignored, repressed, or denied by the character who has been cloned (traduzido pelo autor). 
dos movimentos, Caruso passa a destacar a personagem e reforça a morbidez que é própria de seu reflexo melancólico. Diferente da bem iluminada condessa, seu reflexo é apresentado pelo artista na penumbra. ${ }^{8}$ Essa atribuição de pouca luz "confere enorme solidez" à representação, de forma que ela "pareça densa, escultural, difícil de se mover" (NODELMAN, 1988, p.169). ${ }^{9}$

Para Pizarnik (2011, p.34), "esse lá fora contemplado do lá dentro melancólico" constitui "a farsa que todos temos que representar". Ao ler e interpretar o poema Erzsébet Báthory, la Comtesse sanglante, de Valentina Penrose, Pizarnik (ibidem, p. 35) chega à conclusão de que a representação sombria da condessa é uma alegoria da própria melancolia da personagem e lembra que, "na sua época, uma melancólica significava uma possuída pelo demônio".

Do encontro desse eu obscuro com o mundo externo brotam as perversidades e vaidades da condessa, os alívios transitórios para o que Pizarnik (2011) considera o mal do século XVI, a melancolia. Entre tais alívios estavam os banhos de sangue, que serviam para conservar o seu "divino tesouro" (ibidem, p. 39), a juventude e a beleza de que não abria mão. Com a ajuda de Darvúlia, feiticeira que conheceu em 1604 após ficar viúva, ela iniciou-se em jogos mais cruéis. Darvúlia "animou-a a procurar a morte e o sangue em um sentido literal, isto é: a querê-los por si mesmos, sem temor" (ibidem, p.40).

Recorrente em toda a narrativa de Pizarnik (ibidem, p. 17), o sangue é citado quase sempre que a escritora faz menção às torturas promovidas pela condessa, motivos pelos quais "emanava como um gêiser e o vestido branco da dama noturna tornava-se vermelho". Como parte dos ritos de feitiçaria praticados por Báthory sob a orientação de Darvúlia, os banhos que tomava nos remetem à representação do sangue como símbolo revigorante; daí a preferência pela sangria de moças virgens e/ou nobres, filhas de gentis-homens, de cuja pureza emanaria um fluido que, cobrindo-lhe o corpo branco e erguido, seria capaz de "preservar seu viço" (ibidem, p.45). Associando-se culturalmente a "tudo que é belo, nobre, generoso, elevado", o sangue simboliza a vida, é "o veículo da vida" (CHEVALIER e GHEERBRANT, 2001, p. 800).

A opção de Caruso pelo realce aos tons de vermelho, em contraste com o branco e o preto, permitiu um destaque especial ao sangue como elemento simbólico nas ilustrações. Na representação de seus banhos de sangue, o artista representa a condessa como uma espécie de planta cujas raízes mergulhadas no sangue de suas vítimas permitem que se alimente do líquido. Grandes folhagens pendem de onde seriam seus braços, e caveiras ensanguentadas e suspensas por espécies de ramos fazem o papel dos frutos.

8 Para que o intérprete possa perceber as diferenças entre a condessa e seu reflexo, Caruso abdica de uma representação apenas de sua imagem (perspectiva subjetiva) e enquadra as duas figuras, de modo que a ilustração contemple o ponto de vista do leitor. Uma vez que o leitor não foi posicionado atrás da condessa, por exemplo, não há como ele ter acesso ao seu ponto de vista/objeto que ela focaliza.

9 The deep shading gives tremendous solidity to both objects and people, so that they look lumbrous, sculptural, hard to move (traduzido pelo autor). 


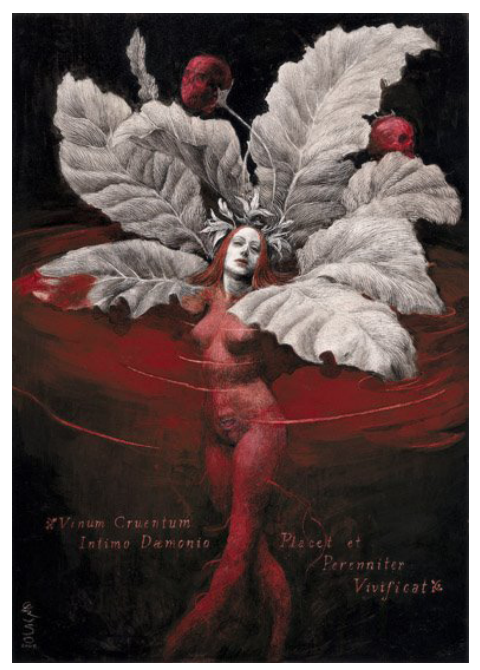

Fig. 5. Os banhos de sangue

Com a cabeça estática como que lembrando a de uma perene e bela escultura (o tom acinzentado da face também confere tal impressão), a condessa de Caruso traz, abaixo de sua cintura submersa, uma bocarra com dentes à mostra, perfil que remete às sereias (sirenes) de tradições greco-romanas e nórdicas tardias, as quais concebem-nas como "criaturas metade mulher, metade peixe", que viviam em "uma ilha do Mediterrâneo, na costa meridional da Itália" (CIVITA, 1973, p. 167). Após atraírem os navegantes com sua beleza e seu belo canto, elas os arrastavam para o mar e os devoravam.

Se compararmos a vida a uma viagem, as sereias aparecem como emboscadas oriundas dos desejos e das paixões. Como vêm dos elementos indeterminados do ar (pássaros) ou do mar (peixes), vê-se nelas criações do inconsciente, sonhos fascinantes e aterrorizantes, nos quais se esboçam as pulsões obscuras e primitivas do homem. (CHEVALIER e GHEERBRANT, 2001, p. 814-815)

A monstruosidade que assemelha a condessa às sereias é, assim, interpretada por Caruso com uma ênfase a elementos relacionados às próprias sereias como símbolos da sedução mortal, o vermelho e o logro de presas ocultas. Além disso, o caráter onírico que envolve o próprio simbolismo dessa figura mitológica é priorizado pela representação excêntrica que o artista faz da condessa: a ilustração a mostra como uma divindade (algo que foge ao mundo palpável), imersa em sangue, revestida de plumagens/folhagens e de cujas pernas surgem raízes.

Essa representação que Caruso faz da condessa em seu banho de sangue (figura 5) também simboliza a dupla polaridade simbólica que compõe muitas personagens góticas: enquanto a fração de seu corpo emergida e visível (adornada até mesmo com uma espécie 
de coroa de flores) remete à formosura e beleza de uma rainha ou deusa, a parte imersa em sangue e dotada de raízes e de uma bocarra heterotópica lembra uma figura fabulosa ou lendária, ${ }^{10}$ conferindo um caráter mais sombrio à ilustração. Lembrando a simbologia anglo-saxônica do sangue de Cristo, que, misturado à água e conservado no Graal, "é, por excelência, a bebida da imortalidade" (CHEVALIER e GHEERBRANT, 2001, p. 800), o sangue que alimenta a condessa é agente direto, dentro da narrativa literária em estudo, da sua juventude. Dessa maneira, o outro atroz, o lado sanguinário da personagem, vive em comunhão com a própria beleza de que se alimenta, mantendo com ela uma estranha familiaridade.

Emilio Soares Ribeiro é doutorando em Estudos Linguísticos na UNESP. É professor do Departamento de Letras Estrangeiras da Universidade do Estado do Rio Grande do Norte (UERN). É membro do Grupo de Estudos de Tradução (GET) da UERN.

emilioribeiro@uern.br

\section{Referências}

BAL, M. Narratology: introduction to the theory of narrative. $3^{\text {rd }}$ ed. Toronto: University of Toronto Press, 2009.

BEHRENDT, S. C. Sibling rivalries: author and artist in the earlier illustrated book. In: Word and Image, vol. 13, $\mathrm{n}^{\circ}$ 1, p. 23-42, 1997.

CARROLL, N. The philosophy of horror: or, paradoxes of the heart. New York e London: Routledge, 1990.

CHEVALIER, J.; GHEERBRANT, A. Dicionário de símbolos. Rio de Janeiro: José Olympio, 2001.

CIRLOT, J. E. Dicionário de símbolos. São Paulo: Editora Moraes LTDA, 1984.

CIVITA, V. (Ed.) Dicionário de mitologia greco-romana. São Paulo: Abril Cultural, 1973.

FRANÇA, J. O insólito e seu duplo. In: GARCÍA, F.; MOTTA, M. A. (org.) O insólito e seu duplo. Rio de Janeiro: EdUERJ, 2009, p. 7-14.

GRIMAL, P. Dicionário da mitologia grega e romana. Rio de Janeiro: Bertrand Brasil, 2000.

GUIMARÃES, L. A cor como informação: a construção biofísica, linguística e cultural da simbologia das cores. São Paulo: Anablume, 2002.

LURKER, Manfred. Dicionário de simbologia. Trad. Mario Krauss e Vera Barkow. São Paulo: Martins Fontes, 1997.

MANGUEL, A. Lendo imagens: uma história de amor e ódio. Trad. Rubens Figueiredo, Rosana Eichemberg e Cláudia Strauch. São Paulo: Companhia das Letras, 2001.

10 Boca heterotópica - deslocada de seu lugar anatômico próprio (o rosto) e transferida a outras partes do corpo em figurações fantásticas (no caso, o ventre). 
NICOLAJEVA, M.; SCOTT, C. How picturebooks work. London/New York: Routledge, 2006.

NODELMAN, P. Words about pictures: the narrative art of children's picture books. Athens/London: The University of Georgia Press, 1988.

PEREIRA, N. M. Traduzindo com imagens: a imagem como reescritura, a ilustração como tradução. Tese (Doutorado). Programa de Pós-Graduação em Estudos Linguísticos e Literários em Inglês, Universidade de São Paulo, 2008.

PIZARNIK, A. A condessa sangrenta. São Paulo: Tordesilhas, 2011.

RIBEIRO, E. S. A relação cinema-literatura na construção da simbologia do Anel na obra O Senhor dos Anéis: uma análise intersemiótica. Dissertação (Mestrado). Programa de Pós-Graduação em Linguística Aplicada, Universidade Estadual do Ceará, 2007.

. Leitura como processo semiótico. In: Leitura em Revista. Cátedra UNESCO de Leitura PUCRio n.1, Out. 2010.

SANTAELLA, L. O que é Semiótica. $3^{\text {a }}$ edição. São Paulo: Brasiliense, 1985

SCHWARCZ, J. H. Ways of the illustrator: visual communication in children's literature. Chicago: American Library Association, 1982.

SOUZA, L. S. Introdução às teorias semióticas. Petrópolis, Rio de Janeiro/Salvador, Bahia: Editora Vozes, 2006.

TREVISAN, J. S. Uma condessa contemporânea. In: PIZARNIK, A. A condessa sangrenta. São Paulo: Tordesilhas, 2011, p. 58-59. 